УДК 615.849 .19

DOI: $10.20535 / 1810-0546.2017 .1 .90044$

\author{
V.B. Maksymenko, V.A. Danilova, V.V. Shlykov* \\ Igor Sikorsky Kyiv Polytechnic Institute, Kyiv, Ukraine

\section{THE DISCRETE MODEL FOR THE SYSTEM OF THE MYOCARDIUM AND CORONARY VESSELS ${ }^{* *}$}

\begin{abstract}
Background. The numerical heat transfer model for a system of myocardium coronary vessels is considered.
Objective. The goal is to develop a discrete model for the physical system of myocardium and coronary vessels that would make it possible to explore the process of hypo- and hyperthermia with cardiopulmonary bypass.

Methods. To solve the differential equation of heat conduction in the MSC Sinda thermal system the network method (TNM - Thermal Network Method) is used, in which system of heat equations is presented in the form of cellular-centered nodes and resistances between the nodes using the finite difference method. In constructing the model of myocardial in the MSC Sinda system the thermal contact between three-dimensional bodies is implemented the myocardium, coronary arteries, a liquid cooling of heart.

Results. Implementation of the model of heat exchange in the MSC Sinda system for infarction cooling process gives on the final process step in establishing the heat balance the temperature difference at the boundary between the myocardium and coronary vessels not more than $0,5^{\circ} \mathrm{C}$. However, in the areas of the myocardium that are removed from the coronary vessels the temperature difference exceeds $1,0^{\circ} \mathrm{C}$. The use of additional cooling for hearts allows for the cooling of myocardium with using of ice surface, that provides the unevenness reduction of the heart temperature during its cooling with cardiopulmonary bypass. This result allows exploring the dynamics of the process of hypo- and hyperthermia with cardiopulmonary bypass.

Conclusions. The discrete 3D-model of heat transfer in the layer structure of the myocardium and coronary vessels allows us to investigate the process of hypo- and hyperthermia with cardiopulmonary bypass. The simulation results also make it possible to perform the analysis of the temperature distribution on the surface of the myocardium provided free convection of heat between the layers.
\end{abstract}

Keywords: thermogram; myocardium; temperature distribution; vascular pathology.

\section{Introduction}

The heart is a complex of pump-muscular system, the functions of which depend on the contractile properties of the myocardium material. The myocardium has a large functional reserve (especially the left ventricle), or the ability to maintain a stable pumping function and a high ability to adapt to stress. The most important question of qualitative information regarding coronary flow was not so easy to solve from the only visible side of the heart in open chest conditions of surgery. In the same time, modern devices and information technologies are giving new solutions, which can be useful during extracorporeal cardiopulmonary bypass (CPB). The existing methods of comparative analysis for thermograms of myocardium allows to obtain the thermal picture for open heart in ranges from $+4{ }^{\circ} \mathrm{C}$ up to $+37{ }^{\circ} \mathrm{C}$ in conditions of $\mathrm{CPB}$ in ranges $+28-+37^{\circ} \mathrm{C}$.

The aim was the expansion of available information about protection of the myocardium and the state of its vascular bed using heat transfer model based on the pericardial temperature propagation in circumstances of CPB. The heat transfer during extracorporeal cardiopulmonary bypass (CPB) is due to the heat exchange between the blood and the water in the heat exchanger device of cardiopulmonary bypass (DCB) and to the heat exchange between the blood and the body of the patient's in the circulatory system. The physical model system of myocardium-coronary vessels consists of 2Dlayer infarction and 3D-structures of the coronary vessels, which are located within the bulk layer.

The numerical model of heat transfer allows estimating the parameters of temperature propagation and temperature gradients at the surface of the myocardium at the time of registration of thermal images of the heart. To solve the differential equation of heat conduction in the MSC Sinda thermal system the network method (TNM - Thermal Network Method) is used. It allows to estimating the parameters of temperature propagation and temperature gradients at the surface of the myo-

\footnotetext{
* corresponding autor: v.shlykov@kpi.ua

${ }^{* *}$ The authors gratefully acknowledge the support of the project AMMODIT funded within EU H2020-MSCA-RICE
} 
cardium at the time of registration of thermal images of the heart.

\section{Problem statement}

The purpose is to create the discrete model for the physical system of myocardium and coronary vessels which is realized on the basis of RCthermal network in the MSC Sinda system for the heat transfer model to 2D-layer myocardium and $3 \mathrm{D}$-structure of the coronary vessels.

\section{The physical model for the system of the myo- cardium and coronary vessels}

The physical model system of myocardiumcoronary vessels consists of 2D-layer infarction and $3 \mathrm{D}$-structures of the coronary vessels, which are located within the bulk layer. In general, differential equation of the heat transfer, that includes transient processes, respectively, convection, diffuse and source terms, has the form [1]:

$$
\begin{gathered}
\rho C_{p} \frac{\partial T}{\partial t}+\operatorname{div}\left(\rho \vec{u} \frac{\partial Q}{\partial t}\right) \\
=-\operatorname{div}\left(\vec{q}_{c}\right)-\operatorname{div}\left(\vec{q}_{R}\right)+\operatorname{div}\left(\theta \cdot \overrightarrow{\operatorname{grad}} \cdot \frac{\partial Q}{\partial t}\right)+q_{v},
\end{gathered}
$$

where $C_{p}$ - the specific heat capacity of the myocardium, $\frac{\mathrm{J}}{\mathrm{kg} \cdot \mathrm{K}} ; \rho-$ the material density (myocardium), $\frac{\mathrm{kg}}{\mathrm{m}^{3}} ; \theta-$ the heat diffusion coefficient in the myocardium, $\frac{\mathrm{m}^{2}}{\mathrm{~s}} ; \vec{u}-$ the heat flow velocity vector, $\frac{\mathrm{m}}{\mathrm{s}} ; \operatorname{div}\left(\vec{q}_{c}\right) \quad-$ the temperature change rate per unit volume due to heat transfer; $q_{c}$ - the heat flux due to heat transfer, $\frac{\mathrm{W}}{\mathrm{m}^{2}}$; $\operatorname{div}\left(\vec{q}_{R}\right)$ - temperature change rate per unit volume due to heat irradiation; $q_{R}-$ the heat flux due to heat irradiation, $\frac{\mathrm{W}}{\mathrm{m}^{2}} ; \operatorname{div}\left(\rho \vec{u} \frac{\partial Q}{\partial t}\right)-$ the convective term; $\operatorname{div}\left(\theta \cdot \overrightarrow{\operatorname{grad}} \cdot \frac{\partial Q}{\partial t}\right)-$ the diffusion term; $\frac{\partial Q}{\partial t}=-\lambda_{p} \frac{\partial T}{\partial n} d S-$ the amount of heat that passing through the surface layer element $d S$ per unit time, $\mathrm{W} ; \lambda_{p}-$ the coefficient of the myocardial thermal conductivity, $\frac{\mathrm{W}}{\mathrm{m} \cdot \mathrm{K}} ; q_{v}-$ the source term, which is the internal heat sources in the material - the myocardium, $\frac{\mathrm{J}}{\mathrm{s} \cdot \mathrm{m}^{3}}$.

If the value of thermal conduction coefficient is constant, the heat transfer in the myocardium is defined as

$$
\operatorname{div}\left(\vec{q}_{c}\right)=-\lambda_{p}\left(\frac{\partial^{2} T}{\partial x^{2}}+\frac{\partial^{2} T}{\partial y^{2}}+\frac{\partial^{2} T}{\partial z^{2}}\right),
$$

where $x, y, z$ - the space coordinates.

Simultaneously with the heat transfer in the myocardium during the hypo- and hyperthermia of heart heat dissipation is also involved, which defines the heat exchange between the myocardium and the environment layer in contact with it - the structure of the coronary vessels. The heat irradiation in accordance with the law of NewtonRichman is proportional to the temperature gradient between the myocardium and coronary vessels:

$$
\operatorname{div}\left(\vec{q}_{R}\right)=\alpha\left(T_{\text {heat }}-T_{\text {liq }}\right),
$$

where $\alpha$ - the heat transfer coefficient, $\frac{\mathrm{W}}{\mathrm{m}^{2} \cdot \mathrm{K}}$; $T_{\text {heart }}-$ the surface temperature of the myocardium, $\mathrm{K} ; T_{\text {liq }}-$ the coolant temperature (perfusion fluid), which is introduced into coronary vessels, $\mathrm{K}$.

If the value of myocardial density is constant over the three spatial directions, the convective term of the heat equation has the form:

$$
\operatorname{div}\left(\rho \vec{u} \frac{\partial Q}{\partial t}\right)=\rho S_{p}\left(\frac{\partial(u T)}{\partial x}+\frac{\partial(u T)}{\partial y}+\frac{\partial(u T)}{\partial z}\right) .
$$

To determine the temperature field in the MSC Sinda system the differential equation of thermal conductivity obtained using the generalized heat equation is used:

$$
\rho C_{p} \frac{\partial T}{\partial t}=-\operatorname{div}(\vec{q})+q_{v},
$$

where $\vec{q}=\vec{q}_{c}+\vec{q}_{R}-$ the rate of temperature change per unit myocardial volume; $q_{v}$ - the distribution density of the structures of the coronary vessels in the myocardium.

In a particular case, for areas of the myocardium which is depleted of the coronary vessels, the internal heat sources in the myocardium may not be available, that means $q_{v}=0$. At the same time, 
for different degrees of non-uniformity of the temperature field, flow velocity vector must satisfy the law of conservation of mass of transferred heat, or the continuity equation, which has the form:

$$
\frac{\partial \rho}{\partial t}+\operatorname{div}(\rho \vec{u})=0
$$

Thus, in general the differential equation considering heat conductivity of the convective flow in the myocardium takes on form [2]:

$$
\left\{\begin{array}{l}
\rho C_{p} \frac{\partial T}{\partial t}+\operatorname{div}\left(\rho \vec{u} \frac{\partial T}{\partial t}\right)=-\operatorname{div}\left(\vec{q}_{c}\right)-\operatorname{div}\left(\vec{q}_{R}\right), \\
\frac{\partial \rho}{\partial t}+\operatorname{div}(\rho \vec{u})=0 .
\end{array}\right.
$$

In tensor form in a Cartesian coordinate system, the equation will be written as

$$
\left\{\begin{array}{l}
\rho C_{p} \frac{\partial T}{\partial t}+\rho S_{p}\left(\frac{\partial(u T)}{\partial x}+\frac{\partial(u T)}{\partial y}+\frac{\partial(u T)}{\partial z}\right) \\
=-\lambda_{p}\left(\frac{\partial^{2} T}{\partial x^{2}}+\frac{\partial^{2} T}{\partial y^{2}}+\frac{\partial^{2} T}{\partial z^{2}}\right)-\alpha\left(T-T_{0}\right), \\
\frac{\partial \rho}{\partial t}+\rho\left(\frac{\partial(u T)}{\partial x}+\frac{\partial(u T)}{\partial y}+\frac{\partial(u T)}{\partial z}\right)=0 .
\end{array}\right.
$$

As a result of the convective heat transfer between the moving blood in the coronary vessels and the myocardium surface the heat transfer is performed with an intensity which is characterized by the heat transfer coefficient:

$$
\alpha=\frac{\lambda_{p}}{l} \mathrm{Nu},
$$

where $\lambda_{p}-$ the coefficient of the myocardial thermal conductivity, $\frac{\mathrm{W}}{\mathrm{m} \cdot \mathrm{K}} ; l-$ the thickness of the myocardial wall, $\mathrm{m} ; \mathrm{Nu}-$ Nusselt number, which characterizes the similarity of the processes of heat transfer at the boundary between the myocardium and coronary vessels.

For laminar blood flow in the system of artificial circulatory the Nusselt number can be expressed as the equation:

$$
\mathrm{Nu}=0,15 \operatorname{Re}^{0,33} \cdot \operatorname{Pr}^{0,43} \cdot \mathrm{Gr}^{0,1} \cdot\left[\frac{\mathrm{Pr}}{\operatorname{Pr}_{\mathrm{st}}}\right]^{0,5} \cdot E_{l},
$$

where $\operatorname{Re}=\frac{v_{\text {liq }} \cdot l \cdot \rho_{\text {liq }}}{\mu_{\text {liq }}}-$ Reynolds number, which characterizes the ratio of inertial forces and friction for the viscous flow; $\operatorname{Pr}=\frac{C_{\text {liq }} \cdot \mu_{\text {liq }}}{\lambda_{p}}-$ Prandtl number that characterizes the physical and chemical properties of the coolant - blood; $\mathrm{Gr}=\frac{l^{3} g \beta_{\text {liq }} \Delta T}{v_{\text {liq }}}-$ Grashof number that characterizes the blood flow in the system in idle mode; $v_{\text {liq }}=\frac{\mu_{\text {liq }}}{\rho_{\text {liq }}}-$ the kinematic viscosity of blood, $\frac{\mathrm{m}^{2}}{\mathrm{~s}} ; \lambda_{p c}-$ the thermal conductivity of the wall of myocardium and coronary vessels, $\frac{\mathrm{W}}{\mathrm{m} \cdot \mathrm{K}} ; \rho_{\text {liq }}$ the blood density, $\frac{\mathrm{kg}}{\mathrm{m}^{3}} ; c_{\text {liq }}-$ the specific heat capacity of the blood, $\frac{\mathrm{J}}{\mathrm{kg} \cdot \mathrm{K}} ; \beta_{\text {liq }}-$ the thermal expansion coefficient of the coolant, $\frac{1}{\mathrm{~K}} ; v_{\text {liq }}-$ the blood flow velocity, $\frac{\mathrm{m}}{\mathrm{s}} ; E_{l}-$ the tabular factor, which depends on the value of the Reynolds number Re; $g$ - the acceleration of gravity, $\frac{\mathrm{m}}{\mathrm{s}^{2}}$; $\Delta T=T_{\text {heart }}-T_{\text {liq }}-$ the temperature difference between the wall of the myocardium and blood in the coronary vessels, $K$.

\section{The discrete form of the heat equation of myo- cardial}

To solve the differential equation of heat conduction in the MSC Sinda thermal system the network method (TNM - Thermal Network Method) is used, in which system of heat equations is presented in the form of cellular-centered nodes and resistances between the nodes using the finite difference method (Fig. 1).

Application of the TNM to the heat equation yields the following discrete form of equation [3, 4]:

$$
\begin{aligned}
& \frac{\partial T_{i}}{\partial t} \approx \frac{1}{\left(m C_{p}\right)_{i}}\left[\sum_{j=1}^{N} C_{i, j}\left(T_{j}-T_{i}\right)+\sum_{j=1}^{N} R\left(T_{j}^{4}-T_{i}^{4}\right)\right] \\
& +\frac{q_{i}}{\left(m C_{p}\right)_{i}}, \quad i=1, \ldots, N,
\end{aligned}
$$

where $\left(m C_{p}\right)_{i}-$ the junction capacitance at node $i$; $N$ - the total number of diffuse network nodes; 


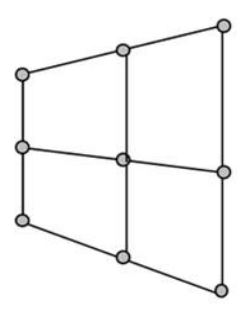

Cellular Element

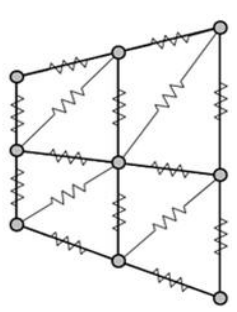

RC-Thermal Network

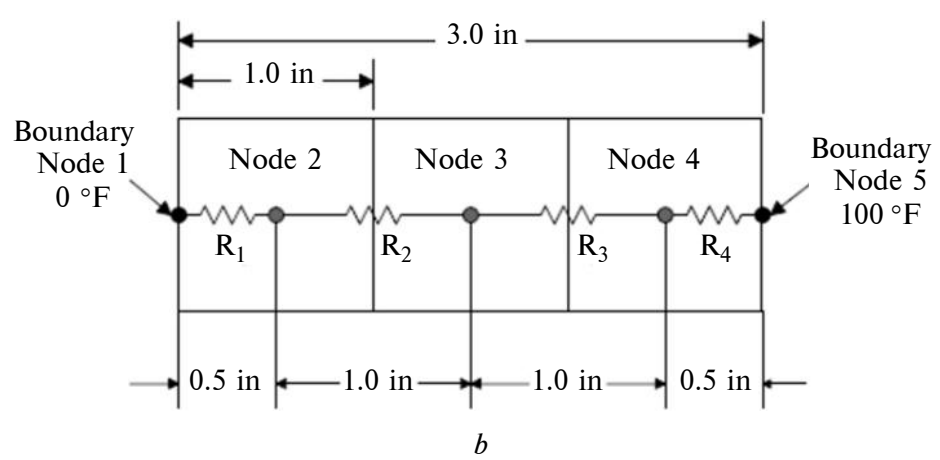

Fig. 1. The discrete model of the RC-thermal network: $a$ - the cellular elements of RC-thermal network; $b-$ the structure of the RC-thermal network

$R_{i, j}$ - the thermal radiation from the resistance between the nodes $i$ and $j$; $C_{i, j}$ - the capacity of linear conductor between nodes $i$ and $j ; q_{i}-$ the distributed of heat sources in the myocardium.

In the model the heat radiation from the resistance between the nodes $i$ and $j$ is a member $R_{i, j}$ which defines a heat transfer from the material - blood and coronary vessels. Discrete formula has the form:

$$
R_{i, j}=\sigma S_{i}^{n} \cdot f_{i, j}
$$

where $\sigma-$ Stefan-Boltzmann constant; $S_{i}^{n}-$ the radiant heat irradiation area; $f_{i, j}-$ the heat factor of the heat radiation, which can be considered the same for constant surgical field with cardiopulmonary bypass.

In the model the linear conductor capacitance between nodes $i$ and $j$ represents a member $C_{i, j}$ that defines the heat transfers to the material - the myocardium and blood. Its discrete formula has the form:

$$
C_{i, j}=\frac{\lambda_{i, j} \cdot S_{i}^{n}}{h_{i, j}},
$$

where $\lambda_{i, j}-$ the effective thermal conductivity between nodes $i$ and $j ; S_{i}^{n}-$ the area of heat conduction between nodes $i$ and $j ; h_{i, j}-$ the distance between the nodes $i$ and $j$.

Since most of the heat conductors in a system of myocardial-blood cannot be considered as homogeneous, the calculation of their values $R_{i, j}$ and $C_{i, j}$ requires to use in the model of thermal resistance. In these cases, the conductivity of the conductor $G_{i, j}$ is calculated as the reciprocal of the contact resistance between the two layers of nodes in the model:

$$
G_{i, j}=C_{i, j}+R_{i, j}\left(T_{i}^{2}+T_{j}^{2}\right)\left(T_{i}+T_{j}\right) .
$$

To solve the heat equation in the MSC Sinda system the modified Dyufort-Frenkel scheme is used. According to this scheme, the heat conduction equation has the form [5]:

$$
\left[1+\frac{\Delta t G_{i, j}}{\left(m C_{p}\right)_{i}}\right] T_{i}^{\tau+1}
$$

$=T_{i}^{\tau}+\sum_{j=1}^{N} \frac{\Delta t \cdot G_{i, j}}{\left(m C_{p}\right)_{i}} T_{i}^{\tau}-\sum_{j=1}^{N} \frac{\Delta t \cdot G_{i, j}}{\left(m C_{p}\right)_{i}} T_{i}^{\tau-1}+\frac{\Delta t q_{i}}{\left(m C_{p}\right)_{i}}$,

where $N$ - the total number of diffusion nodes; $i, j-$ the nodes of thermal RC-network; $\tau-1-$ the previous time of calculation; $\tau+1-$ next (current) one time of calculation; $q_{i}-$ the heat source node $i ; C_{i, j}$ - the overall conductivity between nodes $i$ and $j$.

\section{The myocardium model in the MSC Sinda sys- tem}

In constructing the model of myocardial in the MSC Sinda system the thermal contact between three-dimensional bodies is implemented the myocardium, coronary arteries, a liquid cooling of heart. The model of heat exchange for the local area of the myocardium for two conditions of heat transfer is built: heat conduction and free convection for the myocardial area, which is depleted of the coronary vessels and the myocardial region with double density distribution of the coronary vessels in the myocardium, relative to the case of depleted distribution. 
These three-dimensional objects with embedded in them of thermal RC-network are shown in Fig. 2, $a$ and 2, $b$, respectively.

The heat transfer coefficient under free convection between three-dimensional objects - the myocardium and coronary vessels corresponds to the natural model of convection laminar flow (model number ID $=701$ for Convection Correlation Lib) across the surface with the characteristic length $L$ :

$$
h=\frac{\lambda_{\text {heart-liq }}}{L} \cdot \mathrm{Nu} \text {, }
$$

where $\mathrm{Nu}^{\frac{1}{2}}=0,825+\frac{0,387 \mathrm{Ra}^{\frac{1}{6}}}{\left[1+\left(\frac{0,492}{\mathrm{Pr}}\right)^{\frac{9}{16}}\right]^{\frac{5}{27}}}-$ the

Nusselt number; $\mathrm{Ra}=\mathrm{Gr} \cdot \mathrm{Pr} \quad-$ the Rayleigh number $\left(0,1<\operatorname{Ra}<10^{12}\right)$.

For the laminar flow of blood in the blood vessels, these values are actually determined by

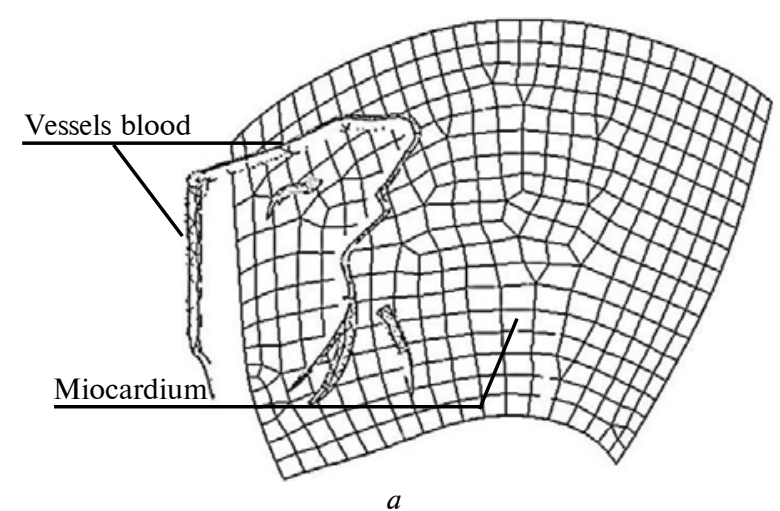

the product $\mathrm{Gr} \cdot \mathrm{Pr}$ of the indicator of the degree $n$ for values $\left[\frac{\mathrm{Pr}}{\operatorname{Pr}_{h t}}\right]^{n}$ and are in the range $1 \cdot 10^{3}<\mathrm{Gr} \cdot \operatorname{Pr}<5 \cdot 10^{2}$.

Implementation of heat transfer model for myocardium cooling process is executed in the Sind MSC system. On the final step myocardium cooling process in establishing the heat balance the temperature difference at the boundary between the myocardium and coronary vessels does not exceed $0,5^{\circ} \mathrm{C}$. However, in the areas of the myocardium that are removed from the coronary vessels the temperature difference exceeds $1,0^{\circ} \mathrm{C}$.

The use of additional cooling for hearts - the cooling of myocardium with using of ice surface, which is at a temperature $T_{\text {liq }} \approx 1^{\circ} \mathrm{C}$ provides the unevenness reduction of the heart temperature during its cooling with cardiopulmonary bypass. The example of numerical heat transfer model, which employs the heat convection between ice cube and the surface of the myocardium, is shown in Fig. 3.

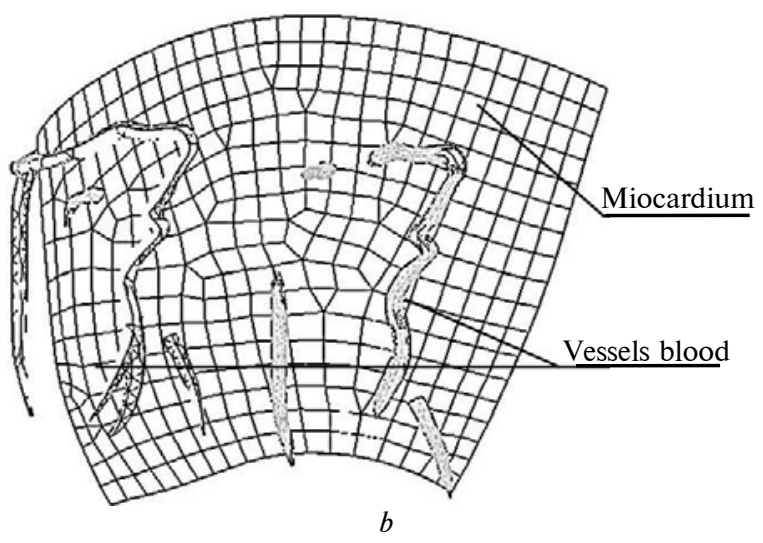

Fig. 2. Model of local fragment of myocardium, coronary vessels and cooling fluid for the heat RC-network in MSC Sinda: $a-$ the myocardium, which is depleted of the coronary vessels; $b$ - the myocardium with twice the density of the coronary vessels.

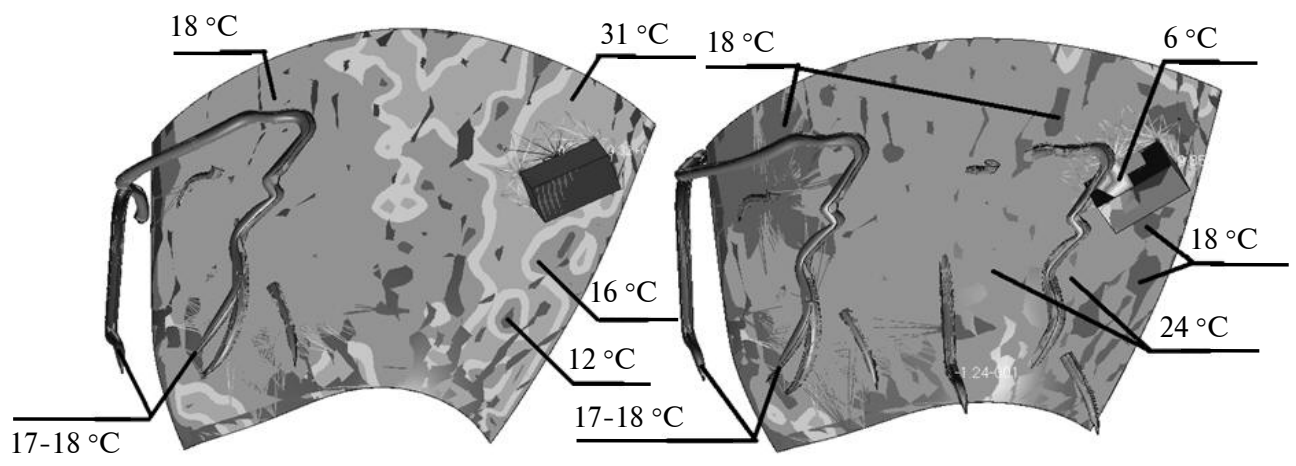

Fig. 3. The distribution of temperatures on the surface of the myocardium, which is further cooled with ice at a temperature $T_{\text {liq }} \approx 1{ }^{\circ} \mathrm{C}$ 
From the analysis of the temperature distribution on the surface of the myocardium can be seen that a large temperature gradient $\Delta T_{1}>\Delta T_{2}$ at the surface of the myocardium, which is depleted of coronary vessels, is caused by insufficient heat exchange between the blood and the myocardium. It is obvious that the lack of heat exchange between the three-dimensional objects in the model - the myocardium and coronary vessels is associated with a decrease in area of the critical section of the myocardium $S_{\text {heart }}$ which has contact with the coronary vessels that filled with blood.

\section{Experimental verification of the heat transfer model}

For experimental verification model of heat transfer that implemented in the MSC Sinda measurements of thermal fields of open heart were performed [6]. With the help of thermal imaging Flir i7 and TermoCAM E300 for 15 patients thermographic images of the myocardium during open heart surgery with cardiopulmonary bypass were recorded - for chilled heart at $24-25^{\circ} \mathrm{C}$, as well as prior to and after the hypothermia at temperature $33-36{ }^{\circ} \mathrm{C}$.

At the images of registered thermograms maximum gradient of temperatures on the surface of the myocardium at the beginning of the process of hypothermia is $\Delta T_{\text {hypo }} \approx 2,0^{\circ} \mathrm{C}$, for cooling the heart $-\Delta T_{\text {cool }} \approx 1,5{ }^{\circ} \mathrm{C}$, and at the end of the process of hyperthermia $-\Delta T_{\text {hyper }} \approx 3,0^{\circ} \mathrm{C}$. Reducing the temperature gradient between the zones of uneven cooling for the myocardium to the value of $\Delta T_{\text {cool }} \approx 1,5^{\circ} \mathrm{C}$ is explained by the state of heat balance for chilled heart, and the heart is excluding from the circulation blood in the application of cardiopulmonary bypass.
Application of model of heat exchange for problem of cooling infarction provided stationary convection laminar flow across the border surface of blood-myocardium gives the value of convection coefficient, respectively, $h_{1} \approx 4,70 \frac{\mathrm{W}}{\mathrm{m}^{2} \cdot \mathrm{K}}$ and $h_{1} \approx 4,70 \frac{\mathrm{W}}{\mathrm{m}^{2} \cdot \mathrm{K}}$ in establishing the heat balance. These values the coefficients of convection correspond to the inner surface temperature - for coronary vessels $\Delta T_{\text {int }} \approx 5^{\circ} \mathrm{C}$, and the external surface temperature - for not cooled myocardium $\Delta T_{\mathrm{ext}} \approx 35^{\circ} \mathrm{C}$.

\section{Conclusions}

Thus, a discrete 3D-model of heat transfer in the layer structure of the myocardium and coronary vessels allows us to investigate the process of hypoand hyperthermia with cardiopulmonary bypass. The simulation results also make it possible to perform the analysis of the temperature distribution on the surface of the myocardium provided free convection of heat between the layers.

The 3D numerical heat transfer model in the myocardium takes into account real specific heat of human heart, the initial temperature distribution and free convection mechanism in the myocardium, and also allows calculating the rate of cooling of the myocardium and to determine the presence of ischemic lesions on the surface of the myocardium. Comparison of the model with real patients IRT shows that this method can provide additional important information regarding temperature and vascular uniformity in time of myocardial cooling and heating.

\section{References}

[1] J.H. Lienhard IV and J.H. Lienhard V, A Heat Transfer Textbook. Cambridge, UK: Phlogiston Press, 2016.

[2] J.R. Howell et al., Thermal Radiation Heat Transfer. New York: CRC Press, Taylor \& Francis Group, 2011.

[3] P. Moin, Fundementals of Engineering Numerical Analysis. New York: Cambridge University Press, 2010.

[4] A.K Oppenheim, "Radiation analysis by the network method", Trans. ASME, pp. 54, 1954.

[5] Astrium, SINDA User Manual, ver. 3.2, 2003.

[6] I.U. Khudetsky et al., "Use of thermal imaging for control of the process hypothermia cardiac", The Polish J. Appl. Sci., vol. 1, no. 3, pp. 93-96, 2015. 


\section{В.Б. Максименко, В.А. Данілова, В.В. Шликов}

\section{ДИСКРЕТНА МОДЕЛЬ СИСТЕМИ МІОКАРД-КОРОНАРНІ СУДИНИ}

Проблематика. Розглядається реалізація числової моделі теплообміну для системи міокард-коронарні судини.

Мета дослідження. Розробка дискретної моделі фрізичної системи міокарда та коронарних судин, яка б дала змогу досліджувати процес гіпо- та гіпертермії в умовах штучного кровообігу.

Методика реалізації. Для розв'язання диференціального рівняння теплопровідності в системі MSC Sinda використано метод теплової мережі (TNM), у якому система рівнянь теплопровідності представлена за допомогою скінченнорізницевого методу у вигляді клітино-орієнтованих вузлів і опорів між вузлами. При побудові моделі міокарда в системі MSC Sinda реалізований тепловий контакт між тривимірними тілами - міокардом, коронарними артеріями, рідиною для охолодження серця.

Результати дослідження. Реалізація моделі теплообміну в системі MSC Sinda для процесу охолодження міокарда дає на кінцевій стадії процесу, при встановленні теплового балансу, різницю температур на межі між міокардом і коронарними судинами температур не більше $0,5^{\circ} \mathrm{C}$. При цьому в областях міокарда, які віддалені від коронарних судин, різниця температур перевищує $1,0^{\circ} \mathrm{C}$. Використання додаткового охолодження для серця передбачає охолодження міокарда 3 використанням поверхні льоду, що забезпечує зниження нерівномірності розподілу температури серця при його охолодженні штучним кровообігом. Цей результат дає змогу досліджувати динаміку процесу гіпо- та гіпертермії в умовах штучного кровообігу.

Висновки. Дискретна 3D-модель теплопередачі для системи шар міокарда-коронарні судини дає змогу досліджувати процес гіпо- та гіпертермії в умовах штучного кровообігу. Результати моделювання також дають можливість провести аналіз розподілу температури на поверхні міокарда за умови вільної конвекції тепла між шарами.

Ключові слова: термограма; міокард; розподіл температур; судинна патологія.

\section{В.Б. Максименко, В.А. Данилова, В.В. Шлыков}

\section{ДИСКРЕТНАЯ МОДЕЛЬ СИСТЕМЫ МИОКАРД-КОРОНАРНЫЕ СОСУДЫ}

Проблематика. Рассматривается реализация численной модели теплообмена для системы миокард-коронарные сосуды.

Цель исследования. Разработка дискретной модели физической системы миокарда и коронарных сосудов, которая позволила бы исследовать процесс гипо- и гипертермии в условиях искусственного кровообращения.

Методика реализации. Для решения дифференциального уравнения теплопроводности в системе MSC Sinda использован метод тепловой сети (TNM), в котором система уравнений теплопроводности представлена с помощью конечноразностного метода в виде клеточно-ориентированных узлов и сопротивлений между узлами. При построении модели миокарда в системе MSC Sinda реализован тепловой контакт между трехмерными телами - миокардом, коронарными артериями, жидкостью для охлаждения сердца.

Результаты исследования. Реализация модели теплообмена в системе MSC Sinda для процесса охлаждения миокарда дает на конечной стадии процесса, при установлении теплового баланса, разность температур на границе между миокардом и коронарными сосудами температур не более $0,5^{\circ} \mathrm{C}$. При этом в областях миокарда, которые удалены от коронарных сосудов, разность температур превышает $1,0^{\circ} \mathrm{C}$. Использование дополнительного охлаждения для сердца предусматривает охлаждение миокарда с использованием поверхности льда, что обеспечивает снижение неравномерности распределения температуры сердца при его охлаждении искусственным кровообращением. Этот результат позволяет исследовать динамику процесса гипои гипертермии в условиях искусственного кровообращения.

Выводы. Дискретная 3D-модель теплопередачи для системы слой миокарда-коронарные сосуды позволяет исследовать процесс гипо- и гипертермии в условиях искусственного кровообращения. Результаты моделирования также дают возможность провести анализ распределения температуры на поверхности миокарда при свободной конвекции тепла между слоями.

Ключевые слова: термограмма; миокард; распределение температур; сосудистая патология.

Рекомендована Радою

факультету прикладної математики

КПІ ім. Ігоря Сікорського
Надійшла до редакції

12 січня 2017 року 